S. Banfi, M. Filippini

Resource rent taxation and benchmarking : a new perspective for the Swiss hydropower sector

Quaderno N. 09-06

Decanato della Facoltà di Scienze economiche

Via G. Buffi, $13 \mathrm{CH}-6900$ Lugano 


\title{
Resource Rent Taxation and Benchmarking - A New Perspective for the Swiss Hydropower Sector
}

\author{
Silvia Banfi ${ }^{{ }^{*}}$ and Massimo Filippini ${ }^{\mathrm{a}, \mathrm{b}}$
}

a) Centre for Energy Policy and Economics, ETH Zurich, Zürichbergstrasse 18, ZUE, CH8032 Zurich, Switzerland,

Tel.-Nr.: ++41163206 50, Fax-Nr.: ++4116321050

sbanfi@ethz.ch

b) Università della Svizzera italiana, Department of Economics, Via Giuseppe Buffi 13, $\mathrm{CH}-6900$ Lugano, Switzerland and

Centre for Energy Policy and Economics, ETH Zurich, Zürichbergstrasse 18, ZUE, CH8032 Zurich, Switzerland

* Corresponding author

\section{Abstract}

The electricity generation in Switzerland is mainly based on hydropower (55\% of total production). The exploitation of water in the hydropower sector can generate significant so-called resource rents. These are defined by the surplus return above the value of capital, labor, materials and energy used to exploit hydropower.

In Switzerland, hydropower producers pay to the State a fixed fee per kW gross capacity. With this system the substantial differences in costs, revenues and in the production characteristics of the hydropower plants are not taken into account.

In this context, the following paper has two main goals: 1) To discuss the introduction in the Swiss hydropower sector of a new payment system based on a resource rent tax; 2) To propose a combination of a RRT system with a benchmarking analysis of the production cost obtained through the estimation of a stochastic frontier variable cost function.

We estimate a true random effects stochastic frontier variable cost function using panel data in order to overcome the asymmetric information problem. In addition, using the information on cost efficiency of the single companies, we show how to introduce in the RRT scheme a benchmark system which gives incentives to minimize the production costs.

Keywords: Resource Rent Taxation; Hydropower; Efficiency 


\section{Introduction}

In Switzerland, electricity is mainly produced by hydropower companies, which employ labor, capital and waterpower.' The exploitation of this important natural resource can generate significant economic rents ("resource rents") given by the surplus return above the value of the capital, labor, materials and other inputs employed to exploit the resource (Rothman, 2000).

The right to utilize the waterpower is granted to the Swiss hydropower companies by the cantonal governments. Of course, the cantonal governments seek compensation for the rights granted to use waterpower. The reason to demand payment is that there is an economic value involved in the use of hydropower. For some Alpine cantons the revenues from water fees and taxation of hydropower companies account for more than $10 \%$ (up to 20\%) of overall revenues. These water fees are even more important for certain municipalities with a share of more than $50 \%$ of overall revenues. Therefore, a reform of the water fee system has important political and economic implications and requires a careful implementation (Banfi et al., 2004).

Today, the Swiss hydropower producers pay a fixed fee per kW gross capacity of the plants, irrespective of their cost structure or revenue possibilities. The fee amounts to as much as 20\%-30\% (including direct taxes ${ }^{2}$ ) of the total production costs of hydropower producers.

From the economic point of view, the current payment method is not satisfactory, because it does not reflect the value of the resource rent which varies considerably among the companies. ${ }^{3}$ Indeed, this is the case because of the very heterogeneous cost structure, due, for example, to the different locations of the

\footnotetext{
${ }^{1}$ The Swiss electricity sector is mainly based on hydropower generation $(\sim 55 \%)$ and on nuclear power generation $(\sim 40 \%)$. The production of electric power using thermal power plants or using wind or photovoltaic energy is currently limited $(\sim 5 \%)$. The run-of-river hydro power plants and the nuclear power plants are utilized principally to meet the demand for electricity at a national level during the medium and low load periods, whereas the storage and the pump storage power plants are employed to satisfy the electricity demand during the high load periods. The cantonal governments own the majority of these hydropower companies directly or indirectly (through some of the overland companies).

${ }^{2}$ Which are the minor part of the total tax burden.

${ }^{3}$ See Banfi et al. (2005) for a first assessment of the magnitude of economic rent in the Swiss hydropower sector.
} 
plants, and revenue possibilities, resulting, for instance, from different shares of peak load electricity produced by run-of-river and storage plants. Therefore, for some hydropower producers the amount of this rent can be lower or higher than the fixed fee they have to pay with the current system. Of course, until now the hydropower plants with a lower resource rent per kWh than the fixed fee were able to increase the final consumer price because they were operating in a monopoly situation. However, with the ongoing stepwise market liberalization of the Swiss electricity market, which started in January 2009 with the free choice of electricity supplier for large consumers (above 100'000 kWh per year) this possibility will be excluded.

From the economic point of view a resource rent tax (RRT) would be a satisfactory payment system for two main reasons ${ }^{4}$.

$>$ First, it is connected directly to the economic value of the resource and thus enhances allocative efficiency.

$>$ Second, it is - compared to other rent extraction schemes - neutral to investment decisions since marginal firms are not taxed, and thus the competitiveness of the industry is secured ${ }^{5}$. In the long run the current inflexible water fee system could make some hydropower companies unprofitable. Given complete market liberalization, some hydropower producers are likely to refuse to renovate their plants in case the production costs (including water fees) can no longer be covered by the expected market prices. By contrast, if the water fees were based on the value of the resource rent, these companies - or at least part of them would decide to renovate their plants, as long as total costs can be covered by the expected market prices ${ }^{6}$. Thus, in order to guarantee the long-term competitiveness of Swiss hydropower companies, it would be important to introduce a resource rent tax system. ${ }^{7}$

In spite of the economic advantages, the change from a fixed fee system to an RRT is politically controversial as water fees are an important source of revenue for the

\footnotetext{
${ }^{4}$ See Copithorne et al. (1985) and Watkins (2001) for a presentation and discussion of the RRT and other taxation systems or Amundsen et al. (1992) for a discussion of the application of these instruments in the (Norwegian) hydropower sector.

${ }^{5}$ For a first analysis of the competitiveness of the Swiss hydropower sector in a liberalized market see Banfi et al. (2002).

${ }^{6}$ For an empirical analysis of the impact of a RRT on the decision to renovate the production plants see Banfi et al. (2004).

${ }^{7}$ The current discussion about a more flexible water fees system is particularly important since in few years several licenses for the use of hydropower by the companies will expire. With the renewal of licenses much more restrictive constraints for the low flow have to be realized, which will have important impacts on the production and therefore on the revenues of firms. This may additionally weaken the competitive position of some hydropower plants.
} 
cantonal governments and a change in the payment system would entail considerable regional financial effects.

A resource rent tax is an interesting water fee system. However, this system has a drawback, it does not include strong incentives to operate efficiently, e.g. at the minimum cost. This incentive is particularly low if the tax rate is $100 \%$ of the RR. Also with a tax rate lower than $100 \%$ this incentive remains weak. This means that a company does not have incentives to reduce cost because it cannot internalize the benefit of the effort.

In order to introduce incentives to improve the cost efficiency of the companies the state could adopt the following strategies:

1. Introduce a RRT rate lower than $100 \%$. In this case the benefit of an improvement of the level of the cost efficiency would be shared between the company and the state.

2. Combine a RRT system with a benchmarking analysis of the cost of the hydropower companies. Firms characterized by cost inefficiency would be punished in the computation of RRT.

3. A combination of points 1) and 2).

This paper has two main goals:

1. To discuss the introduction in the Swiss hydropower sector of a new payment system based on a resource rent tax;

2. To propose a combination of a RRT system with a benchmarking analysis of the production cost obtained through the estimation of a stochastic frontier variable cost function.

The basic idea of this paper is to recommend the integration of the results of an econometric frontier variable cost function in an RRT system. This integration can reduce the asymmetric information problem about production costs the government faces when assessing the RRT and increase costs efficiency of companies. ${ }^{8}$

${ }^{8}$ Of course, we are aware that the estimation of the level of the resource rent needs also information on the revenues of the companies. This information can be taken from the annual reports (ex post) or can be forecasted (ex ante or ex post estimation of the revenues). This paper focuses on the combination of the RRT with the estimation of a cost frontier function and will not develop further the discussion of the estimation of the revenues. Of course, also in this case a RRT system with a tax rate of $100 \%$ does not give incentives to the companies to maximize the revenues. A possibility to solve this problem could be to use an econometric 
This paper is structured as follows: In section 2 we will introduce the concept of resource rent, give an outline of the different rent extraction schemes and illustrate the problems arising with a fixed water fee system. Based on these concepts, we will propose a new rent extraction scheme for the Swiss hydropower sector. In section 3 we will specify the stochastic frontier variable cost function used for the empirical part of the analysis. In section 4 we illustrate the characteristics of the database and present and discuss the empirical results. Finally, in section 5 we will complete the paper with the main conclusions and policy implications.

\section{A resource rent tax for the Swiss hydropower sector}

As previously explained, from an economic point of view the price for the use of a resource should be connected to the concept of economic rent or, using the term applied to natural resources, to the resource rent.

Resource rent can be divided mainly into two different kinds: differential and scarcity rent. Differential rent arises because of (innate) differences of production sites, as described before, whereas scarcity rent emanates from the restricted supply of the good, due to natural or political circumstances. Both kinds of rent arise from the characteristics of the natural resource and their sum is therefore called "resource rent". 9 One has to note, however, that other authors (Amundsen et al., 1992; Amundsen and Tjotta, 1993; Amundsen, 1997; Bernard, 1982; Gillen and Wen, 2000) define resource rent as scarcity rent only and use the term "hydro rent" to describe economic rent arising from hydropower production. Nevertheless, Amundsen (1997) and Amundsen and Tjotta (1993) remark: „It is interesting to note, however, that hydro rent also possesses one of the characteristics of resource rent since water contained as storage in a dam is seasonally scarce and, thus is regulated according to its "water value", i.e. a positive marginal user cost which is normally associated with resource rent".

Generally, a resource rent is a surplus value, i.e., the difference between the price and the average production costs of a good. In Ricardo's (1817) classical example, resource rent accrues due to the different productivity levels of different agricultural production sites. A site with less favorable characteristics will - ceteris paribus - face

model to estimate the maximal revenues. This analysis is, however, beyond the goal of this paper.

${ }^{9}$ See van Kooten and Bulte (2000) for a discussion. 
higher production costs, and thus make lower profits (in the case of a free market with exogenously given prices). The marginal firm will only be able to cover its production costs and not receive any resource rent. Similarly, in the hydropower sector it can be observed that some producers face ideal conditions to construct and operate a plant, whereas other firms have to build their plants in locations with more difficult site characteristics, and thus have higher investment and operation costs for a given output. The producers of these plants earn a lower resource rent in comparison with other plants operating in more favorable environmental conditions. In a competitive market, the resource rent reflects the "true economic value" of the natural resource exploited.

In a competitive electricity market, the concept of resource rent can be illustrated graphically using the demand and supply curves.

Figure 1 shows the production situation of four different companies that operate in different regions with constant returns to scale. Firms $U_{1}, U_{2}, U_{3}$ and $U_{4}$ differ only in the average production costs. The equilibrium price is determined by the intersection of the aggregate demand and supply curves.

Figure 1: Different producers and resource rent (marginal costs=average costs)

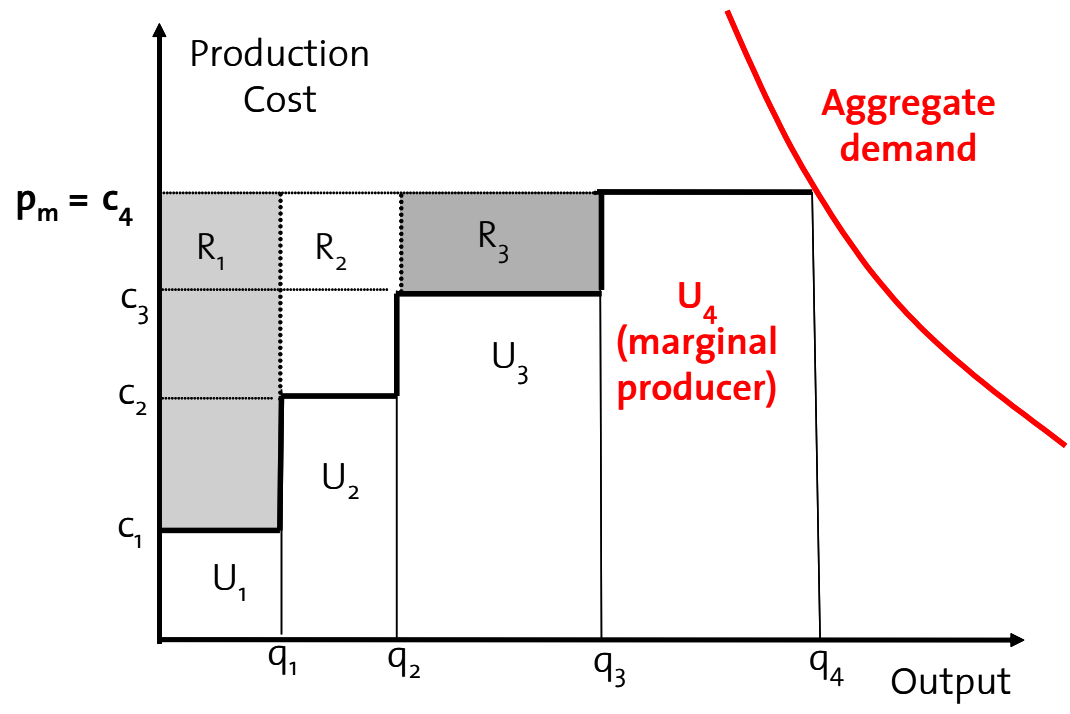

In Figure 1 producer $U_{4}$ is the marginal producer in this setting, and thus just covers his average/marginal costs at market price $p_{m}$. Any other producer showing higher production costs will thus not be able to cover his costs at this price and therefore not participate in the market. Producers $U_{1}, U_{2}$, and $U_{3}$ do earn a resource rent in this situation, since their production costs are lower than the effective market 
price. These rents indicated by $R_{1}$ to $R_{3}$ identify the difference between the effective market price $\left(p_{m}=c_{4}\right)$ and the respective production costs. ${ }^{10}$

The current payment method for the use of hydropower applied in Switzerland is a fixed fee per kW gross capacity and, therefore, is not based on the resource rent concept. Hence, an alternative pricing scheme should be considered in order to promote the efficiency and competitiveness of this sector.

There are a variety of rent extraction mechanisms, an overview and evaluation of these different approaches is given by Watkins (2001), for example. In the following we will concentrate on the so-called resource rent tax (RRT), first put forward by Garnaut and Clunies Ross (1975), which is the concept we propose in order to fix the price hydropower producers have to pay to the owner of the resource (the government). A resource pricing based on the RRT is, from an economic point of view, the best pricing scheme, because it is connected directly to the economic value of the resource. Therefore, the RRT can strengthen the competitiveness of the companies in a liberalized market (protecting marginal producers). Furthermore, it is neutral to investments and flexible in a changing economic environment ${ }^{11}$. In addition, it gives the possibility to introduce incentives for improvements in cost efficiency, as will be illustrated in this paper.

There are two main approaches to the implementation of a RRT in the hydropower sector:

1. A cash-flow based approach, which addresses the hydropower project as a whole and applies when the accumulated revenues exceed accumulated costs (taking into account the respective interest rate). In this system, an "immediate" depreciation takes place and thus the tax is paid only after several years of operation of the hydropower plant.

2. A RRT based on profits, which is very similar to a profit tax but includes an annual depreciation plus deductible cost of capital in the calculation of the resource rent.

The cash-flow based approach could be implemented for new power plants and would, especially in a deregulated market, lower the risk of such long-term investments. In fact, the companies pay a resource rent tax only if positive net returns

${ }^{10}$ Of course, it could also be possible to present a situation with two types of electricity demand: peak and off-peak demand. In such a situation, the economic rent of firms $U_{1}, \cup_{2}, U_{3}$, and $U_{4}$ would vary with time.

"See Watkins (2001) or Banfi et al. (2004) for a more detailed comparison of the different taxation approaches using the relevant appraisal criteria. 
are gained. However, in a situation where the power plants are already running, the second approach would be more appropriate, since, otherwise, one would have to get information on past investments, expenditures and amortizations. In most situations this might not be feasible.

Since we are interested in the introduction of a RRT for the current Swiss hydropower companies, and considering that in the coming years just few new hydropower plants will be constructed (if at all), we decided to adopt the second approach for our estimations.

When implementing an RRT, it is, first of all, necessary to define the costs of hydropower producers and the relevant revenues.

Regarding production costs, it has to be decided which cost components are to be considered and how they are to be defined. One crucial point is the definition of capital costs: For the RR, the capital costs should include some "reasonable" rates of return for external and equity capital. ${ }^{12}$ It must be pointed out that the only difference between the quantitative definition of the RR and the company profit ${ }^{13}$ lies in the different assessments of the capital cost components (the costs of equity capital are not considered in the calculation of the profits). A further difference could be given by the level of the variable costs used for the computation of the RR (for instance by considering the cost inefficiency of the companies).

In order to calculate the RRT, the government could use two approaches. In the first approach the government could directly use the information on total costs and total revenues presented in the annual reports of the hydropower companies. As already discussed, the main problems of this method in the Swiss hydropower sector are:

a) Most of the hydropower companies are so-called partner companies, which supply electricity to their owners, who bear the production costs. ${ }^{14}$ Other producers have long-term contracts with prices that are not disclosed to the public. As a consequence, the revenues reported by the partner companies nowadays do not reflect the market prices and accordingly the scarcity of the resource. This market structure is a

\footnotetext{
${ }^{12}$ The definition of the rate of return of outside capital raises usually less problems since there exist market respectively book values for it.

${ }^{13}$ Besides the conceptual ones, like understanding the rent as the value of the resource, etc.

${ }^{14}$ In Switzerland approximately 80 hydropower and 5 nuclear power companies primarily organized as partner companies ("Partnerwerke") are involved in the generation. It is important to note that in a partner company a shareholder has the right to claim a share of the electricity produced in accordance with the amount of their share capital.
} 
characteristic of the Swiss electricity sector. Although we are aware that a prediction of revenues would be important in order to estimate the $R R T$, in this paper the focus is on the estimation of the cost inefficiency.

b) Companies might have an incentive problem to produce at a cost minimizing level because the benefits of a cost reduction are captured by the local government through a RRT with a levy rate of $100 \%$. But also with a levy below 100\% companies may not have enough incentives to produce at a cost minimizing point. This cost inefficiency in the hydropower production could reduce the amount of the resource rent to be collected by the government.

To solve the cost inefficiency problem, in this paper we propose to estimate for each hydropower plant a cost inefficiency indicator based on the estimation of a frontier variable cost function that should be considered in the computation of the RRT. An estimation of total costs (including capital costs) would make less sense, since, due to the long-term time horizon of the investments (50-80 years), the capital costs of existing plants can be considered fixed ${ }^{15}$.

Taking this discussion into account, we arrive at a general formula for the computation of the resource rent (RR) and of the resource rent tax (RRT), respectively, that can be applied for the Swiss hydropower market.

$$
R R_{i t}=T R_{i t}-D C C_{i t}-\left(V C_{i t}^{*}\left(1-C I N_{i t}\right)\right)
$$

where $T R_{i t}$ are the total revenues for company $i$ in year $t, D C_{i t}$ is the deductible capital cost, $\mathrm{VC}_{\text {it }}$ are the observed variable cost and $\mathrm{CIN}_{\mathrm{it}}$ is the level of cost inefficiency of the company. In this formula, the observed variable cost is corrected for the level of cost inefficiency of the company. The RRT will then be calculated with the following expression:

$$
R R T_{i t}=\% *\left(R R_{i t}\right)
$$

The percentage of the RRT will be fixed by the local government. This mechanism introduces a clear incentive for the hydropower company to minimize the cost. For instance, if a company already produces at the minimum of variable costs then $\mathrm{CIN}_{\mathrm{it}}$ is $\mathrm{O}$ and the computation of the RRT takes into account the $\mathrm{VC}_{\text {it }}$ obtained from the accounting information system of the company. If the firm shows a cost inefficiency level (CIN) of $20 \%$ (the variable cost is $20 \%$ higher then the minimum

${ }^{15}$ It is therefore not possible for the firms to change these investments. We are aware that these costs may not reflect an efficient investment policy of the companies. As a mean of 
variable cost), then the observed cost will be reduced by $20 \%$. This implies an increase of the RR and, therefore, an increase of the RRT. Of course, if the levy is lower than $100 \%$, then a further mechanism that gives incentives to the company to minimize the variable cost is present. In fact, a reduction of the variable cost will increase the RR, but only a fraction of it will be capture by the RRT. Part of this reduction can be kept by the company.

\section{Specification of the frontier variable cost function for the hydropower plants}

A frontier variable cost function identifies the minimum costs at a given output level, input price, capital stock and existing production technology. It is unlikely that all firms will operate at the frontier. Failure to attain the cost frontier implies the existence of technical and allocative inefficiency. In this paper we consider the estimation of a stochastic frontier variable cost function using panel data. ${ }^{16}$ In order to estimate this frontier, it is necessary to specify a model and choose a functional form and an econometric approach.

The main costs of operating a hydropower company comprise the costs of building and maintaining the dam, the steel lined pressure shaft, the power house and the turbines. Moreover, these costs may depend upon the size of the reservoir, the type of the hydropower plant (storage or run-of-river) as well as the number of plants operated by a single company. In fact, the Swiss hydropower companies partly operate several plants located in the same region. Therefore, an analysis of the cost structure of these companies should take account of the fact that the same quantities of electricity can be produced using several plants and/or different types of plants (storage, pump-storage and run-of-river). In the cost model specification it is therefore important to introduce some variables related to both the type of the power plants employed in the production and the organization of the companies.

In the cost model of the hydropower plants we consider one single output. Inputs consist primarily of labor, material and capital. ${ }^{17}$

minimal monitoring, one could limit the allowed capital costs at an upper limit for the rate-of return (including a risk premium) and control for special depreciation.

${ }^{16}$ Different approaches can be used to estimate a frontier cost function. A good overview is given by Battese (1992) and Kumbhakar and Lovell (2000).

${ }^{17}$ The cost model specification used in this paper reflects the model used by Filippini and Luchsinger (2007). These two authors estimated a variable cost function to obtain information on the economies of scale. In the present study we estimate a frontier variable cost function in order to get information on the cost efficiency level of the companies. This is the main difference between the two studies. 
Assuming that output and input prices are exogenous, and that (for a given technology) firms adjust input levels so as to minimize costs, the firm's total cost of operating an hydropower company can be represented by the cost function

$$
V C=V\left(Q, N, P_{L}, C, D_{R 1}, D_{R 2}, D_{S}, D_{P S}, T\right)
$$

where VC represents variable cost, $Q$ is the output represented by the total number of GWh produced and $N$ is the number of plants. $P_{L}$ is the price of labour and and $C$ stands for the capital stock described as the book value of the companies. Unfortunately, we could not consider the price of material in the model specification (3) due to lack of data. ${ }^{18}$

Finally, we introduced 4 dummy variables $\left(D_{R 1}, D_{R 2}, D_{S}, D_{P S}\right)$ in the model to control for differences in cost among different types of hydropower plants used by the companies: run-of-river with an exploitable drop above $25 \mathrm{~m}$, run-of-river with an exploitable drop below $25 \mathrm{~m}$ storage and pump-storage plants. T, the time trend, is included as a way of capturing the effects of neutral technical change.

The properties of cost function (3) are that it is concave and linearly homogeneous in input prices, non-decreasing in input prices and output, and, regarding capital stock, non-increasing ${ }^{19}$.

To estimate the cost function (3), a translog functional form is employed. This flexible functional form is a local, second-order approximation to an arbitrary cost function. It places no a priori restrictions on the elasticities of substitution and allows the economies of scale estimate to vary with the output level. ${ }^{20}$ The translog approximation to (3) is

$$
\begin{aligned}
\ln (\mathrm{VC}) & =\alpha_{0}+\alpha_{\mathrm{Q}} \ln \mathrm{Q}+\alpha_{\mathrm{N}} \ln \mathrm{N}+\alpha_{\mathrm{PL}} \ln \mathrm{P}_{\mathrm{L}}+\alpha_{\mathrm{C}} \ln \mathrm{C}+\frac{1}{2} \alpha_{\mathrm{QQ}}(\ln \mathrm{Q})^{2}+\frac{1}{2} \alpha_{\mathrm{NN}}(\ln \mathrm{N})^{2}+\frac{1}{2} \alpha_{\mathrm{PLPL}}\left(\ln \mathrm{P}_{\mathrm{L}}\right)^{2} \\
& +\frac{1}{2} \alpha_{\mathrm{CC}}(\ln \mathrm{C})^{2}+\alpha_{\mathrm{QN}}(\ln \mathrm{Q})(\ln \mathrm{N})+\alpha_{\mathrm{QPL}}(\ln \mathrm{Q})\left(\ln \mathrm{P}_{\mathrm{L}}\right)+\alpha_{\mathrm{QC}}(\ln \mathrm{Q})(\ln \mathrm{C})+\alpha_{\mathrm{NPL}}(\ln \mathrm{N})\left(\ln \mathrm{P}_{\mathrm{L}}\right) \\
& +\alpha_{\mathrm{NC}}(\ln \mathrm{N})(\ln \mathrm{C})+\alpha_{\mathrm{PLC}}\left(\ln \mathrm{P}_{\mathrm{L}}\right)(\ln \mathrm{C})+\alpha_{\mathrm{R} 1} \mathrm{D}_{\mathrm{R} 1}+\alpha_{\mathrm{S}} \mathrm{D}_{\mathrm{S}}+\alpha_{\mathrm{PS}} \mathrm{D}_{\mathrm{PS}}+\alpha_{\mathrm{T}} \mathrm{D}_{\mathrm{T}}+\text { uit }+ \text { vit }
\end{aligned}
$$

In this specification, which reflects the standard stochastic frontier approach proposed by Aigner et al. $(1977)^{21}$, the error term is composed of two parts: the first, $u_{i t}$ is a one-sided non-negative disturbance reflecting the effect of costs; the second, $v_{i t}$ is

\footnotetext{
${ }^{18}$ The effect of this input price on cost is considered in the constant.

${ }^{19}$ See Cornes (1992), p. 106.

${ }^{20} \mathrm{~A}$ translog function requires the approximation of the underlying cost function to be made at a local point, which in our case is taken at the median point of all variables. Thus, all independent variables are normalized at their median point.

${ }^{21}$ For estimation purposes, the negative sign on the dependent variable can be ignored. This results in the signs of the estimated coefficient being reversed.
} 
a two-sided disturbance capturing the effect of noise. The standard random error term $v_{i t}$ is assumed to be distributed independent of $u_{i t}$ as i.i.d $\mathrm{N}\left(\mathrm{O}, \sigma_{v}^{2}\right)$, whereas for the non-negative cost inefficiency term $u_{i t}$, we assume a half-normal distribution $\mathrm{N}^{+}\left(\mathrm{o}, \sigma_{u}^{2}\right.$ ) .

Of course, we are aware, that in the model specification (3) some environmental and firm characteristics that influence the cost of the hydropower plants are missing. This unobserved firm specific heterogeneity could, of course, influence the econometric results and, therefore, also the cost inefficiency indicators. However, the literature on the estimation of frontier cost function using panel data has recently proposed some approaches that try to overcome this unobserved heterogeneity problem.

The first use of panel data models in stochastic frontier models goes back to Pitt and Lee (1981) who interpreted the panel data random effects (RE) as inefficiency rather than heterogeneity. Pitt and Lee (1981)'s model is different from the conventional RE model in that the individual specific effects are assumed to follow a half-normal distribution. ${ }^{22}$ A major shortcoming of these models is that any unobserved, time-invariant, firm-specific heterogeneity is considered as inefficiency. In order to solve this problem using panel data, Greene (2005) proposed to extend the stochastic frontier analysis (SFA) model in its original form (Aigner et. al. 1977) by adding a fixed or random individual effect in the model and/or by allowing some coefficients to be random. ${ }^{23}$ The main model used in this paper is the true random effects (TRE) stochastic frontier model proposed Greene (2005). ${ }^{24}$ In this model, that allows distinguishing heterogeneities such as external environmental effects from cost efficiency, the intercept $\left(\alpha_{i}\right)$ is assumed to be a random variable. The translog specification of the TRE stochastic frontier variable cost function is:

$$
\begin{aligned}
\ln (\mathrm{VC}) & =\alpha_{\mathrm{i}}+\alpha_{\mathrm{Q}} \ln \mathrm{Q}+\alpha_{\mathrm{N}} \ln \mathrm{N}+\alpha_{\mathrm{PL}} \ln \mathrm{P}_{\mathrm{L}}+\alpha_{\mathrm{C}} \ln \mathrm{C}+\frac{1}{2} \alpha_{\mathrm{QQ}}(\ln \mathrm{Q})^{2}+\frac{1}{2} \alpha_{\mathrm{NN}}(\ln \mathrm{N})^{2}+\frac{1}{2} \alpha_{\mathrm{PLPL}}\left(\ln \mathrm{P}_{\mathrm{L}}\right)^{2} \\
& +\frac{1}{2} \alpha_{\mathrm{CC}}(\ln \mathrm{C})^{2}+\alpha_{\mathrm{QN}}(\ln \mathrm{Q})(\ln \mathrm{N})+\alpha_{\mathrm{QPL}}(\ln \mathrm{Q})\left(\ln \mathrm{P}_{\mathrm{L}}\right)+\alpha_{\mathrm{QC}}(\ln \mathrm{Q})(\ln \mathrm{C})+\alpha_{\mathrm{NPL}}(\ln \mathrm{N})\left(\ln \mathrm{P}_{\mathrm{L}}\right) \\
& +\alpha_{\mathrm{NC}}(\ln \mathrm{N})(\ln \mathrm{C})+\alpha_{\mathrm{PLC}}\left(\ln \mathrm{P}_{\mathrm{L}}\right)(\ln \mathrm{C})+\alpha_{\mathrm{RI}} \mathrm{D}_{\mathrm{R} 1},+\alpha_{\mathrm{S}} \mathrm{D}_{\mathrm{S}}+\alpha_{\mathrm{PS}} \mathrm{D}_{\mathrm{PS}}+\alpha_{\mathrm{T}} \mathrm{D}_{\mathrm{T}}+\text { uit }+ \text { vit }
\end{aligned}
$$

\footnotetext{
${ }^{22}$ Schmidt and Sickles (1984) and Battese and Coelli (1992) presented variations of this model.

${ }^{23}$ For a successful application of these models in network industries see Farsi et al. (2005) and Farsi et al. (2006).

${ }^{24}$ Although similar extensions have been proposed by several previous authors, Greene (2005) provides effective numerical solutions. For similar models see in particular Kumbhakar (1991) and Polachek and Yoon (1996).
} 
This model treats therefore firm-specific random effects $\left(\alpha_{i}\right)$ and timevarying inefficiency $\left(u_{i t}\right)$ separately and is therefore able to distinguish between the unobserved heterogeneity and inefficiency. In this way it tries to overcome some limitations of the conventional panel data models.

\section{Data and empirical results}

The model is estimated with panel data from a sample of Swiss hydropower companies. Our study is principally based on a database created by using different sources: the Swiss Federal Statistical Office's value added statistics ("Wertschöpfungsstatistik"), the Swiss Federal Energy Office's financial statistics ("Finanzstatistik") and a database created by the Center of Energy Policy and Economics by collecting annual financial and economic reports of the companies. Additional technical information was taken from a database on this sector built up by the Federal Office for Water and Geology.

After this information was collected and the data sets were merged, the final data set consisted of a sample of 60 hydropower companies. However, some of these had to be excluded from the econometric analysis due to missing data. Model (5) has been estimated using an unbalanced panel data set, which includes 43 companies observed over a period that varies from 2 to 7 years (with a total of 263 observations).

The total variable cost per year is equated to the sum of labor, operational (including material) and energy costs. Average annual wage rates are estimated by dividing the labor expenditure by the number of employees. Unfortunately, no information is available to define a price for the use of materials. The capital stock is defined as the book value as reported in the annual financial reports of the companies. ${ }^{25}$ All input prices, total costs and variable costs were deflated to 1996 constant Swiss francs using the Consumer Price Index. Descriptive statistics of the variables included in the model are presented in Table 1.

Table 1: Descriptive statistics of variables included in the model

\begin{tabular}{|l|l|c|c|c|}
\hline Variable & Description & 1. Quartile & Median & 3. Quartile \\
\hline O & Gwh & 223.6 & 428.6 & 855.5 \\
\hline N & number & 1 & 3 & 4 \\
\hline
\end{tabular}

${ }^{25}$ No data were available which would allow the calculation of the capital stock using the perpetual inventory method. 


\begin{tabular}{|l|l|c|c|c|}
\hline PL & CHF per months & $97^{\prime 250}$ & $106^{\prime} 500$ & $116^{\prime} 700$ \\
\hline C & Book value in CHF & 59'700'000 & 145'000'000 & 361'500'000 \\
\hline
\end{tabular}

The composition of the hydropower plants included in the sample is the following: $37 \%$ are pump-storage plants, $27 \%$ storage plants, $15 \%$ run-of-river with an exploitable drop below $25 \mathrm{~m}$ and $21 \%$ run-of-river plants with an exploitable drop above $25 \mathrm{~m}$.

The estimated coefficients and their t-values of the cost model (5) estimated using the TRE stochastic frontier model are presented in table 2. The estimated function is well behaved. Most of the parameter estimates are statistically significant.

A well-defined variable cost function should be increasing with respect to output and input prices, concave with respect to input prices and non-increasing with respect to capital stock.

Since total cost and the regressors are in logarithms and have been normalized, the coefficients are interpretable as cost elasticities. All these coefficients show the expected signs and are highly significant.

The output elasticity is positive and implies that an increase in the production will raise the variable/total cost. A $1 \%$ increase in the quantity of electricity produced will increase the variable cost by approximately $0.45 \%$. This result implies that the Swiss hydropower plants are characterized by economies of utilization. ${ }^{26}$

The labor cost elasticity is positive, implying that the cost function is increasing in this input factor. The cost elasticity with respect to the number of plants is positive and indicates that an increase in the production units will raise variable cost of a hydropower company by about $22 \%$.

\footnotetext{
${ }^{26}$ Caves and Christensen (1988) define a measure of utilization economies as unity divided by a proportional increase in variable cost resulting from a proportional increase in output holding the capital stock constant. Thus, economies of utilization represent variable cost changes when output is increased with capacity constant. According to this definition, we define economies

of utilization (EUVC) as

$$
E U_{V C}=\frac{1}{\frac{\partial \ln V C}{\partial \ln y}} .
$$

We talk of economies of utilization if EUVC is greater than 1 and, accordingly, identify diseconomies of utilization if EUVC is below 1. In the case of EUVC $=1$, no economies or diseconomies of utilization are existing.
} 
The coefficient of capital stock is not significantly different from zero. This result indicates that the regularity condition of non-increasing variable cost with respect to the capital stock is satisfied at the median of the data. ${ }^{27}$

Table 2: Estimation results of the Cobb-Douglas cost function

\begin{tabular}{|c|c|c|}
\hline & \multicolumn{2}{|c|}{ TRE } \\
\hline & Coefficients & t-Values \\
\hline LnO- & 0.447 & $17.366^{* * *}$ \\
\hline $\operatorname{LnP}_{\mathrm{L}}$ & 0.365 & $4.233^{* * *}$ \\
\hline $\operatorname{LnC}$ & 0.023 & 1.336 \\
\hline $\operatorname{LnN}$ & 0.225 & $7.336^{* * *}$ \\
\hline LnQDQ & -0.120 & $-4.068^{* * *}$ \\
\hline $\operatorname{Ln} P_{L} P_{L}$ & 1.064 & 1.654 \\
\hline LnCC & 0.000 & 0.013 \\
\hline LnNN & 0.615 & $8.231^{* * *}$ \\
\hline $\operatorname{LnOP} P_{L}$ & -0.291 & $-2.522^{* *}$ \\
\hline LnOQC & 0.059 & $4.237^{* * *}$ \\
\hline LnOQN & -0.034 & -1.010 \\
\hline $\operatorname{Ln} P_{L} C$ & -0.021 & -.254 \\
\hline $\operatorname{Ln} P_{L} N$ & 0.193 & 1.260 \\
\hline LnCN & -0.183 & $-7.598^{* * *}$ \\
\hline$D_{R 1}$ & 0.161 & $3.811^{* * *}$ \\
\hline$D_{S}$ & 0.399 & $9.274^{* * *}$ \\
\hline$D_{P S}$ & 0.845 & $17.349^{* * *}$ \\
\hline Time & -0.025 & $-7.230^{* * *}$ \\
\hline Constant & 15.052 & $323.353^{* * *}$ \\
\hline Lambda & 2.804 & $4.346^{* * *}$ \\
\hline
\end{tabular}

${ }^{*}$ significant at .1, ${ }^{* *}$ significant at .05, and ${ }^{* * *}$ significant at .01

The dummy variables for the technology of hydropower plants, namely $D_{R_{1}}$ (runof-river with an exploitable drop above $25 \mathrm{~m}$ ), $D_{S P}$ (storage pump plant) and $D_{S}$ (storage plant) - have a significant positive coefficient. This result implies that storage hydropower plants and run-of-river plants situated in the mountains (therefore with a higher exploitable drop) show higher variable costs, because they are more complex and difficult to operate, than run-of-river hydropower plants located along the large

\footnotetext{
${ }^{27}$ For a detailed discussion on this point see Filippini (1996).
} 
rivers. ${ }^{28}$ Finally, turning to the question of technological progress, table 2 indicates that there is evidence of a small negative time shift of the variable cost function. Thus, the negative coefficient of $T$ indicates that the Swiss hydropower companies underwent progressive technical change during the period considered in the analysis.

Table 3 gives the summary statistics of the inefficiency scores resulted from the TRE model. The inefficiency score is defined as $\exp \left(u_{i t}\right)$, where $u_{i t}$ is the inefficiency term obtained from the econometric model. The scores therefore represent the ratio of a company's actual variable costs to a minimum level that would have been achieved had the company operated as cost-efficient as the 'best practice' observed in the sample. These results indicate the presence of cost inefficiency in the hydropower sector.

Table 3: Summary statistics of inefficiency scores

\begin{tabular}{|c|cccc|}
\hline & Minimum & Maximum & Mean & Median \\
\hline Cost inefficiency & 0.027 & 0.81 & 0.187 & 0.152 \\
\hline
\end{tabular}

Table 3 illustrate that in the mean, companies exhibit variable costs which are around 19\% higher than the minimal level which could be reached. The most cost efficient company has variable costs approaching the minimum estimated by the cost function (just $2.7 \%$ higher). On the other side, the variable cost of the least efficient company is $80 \%$ higher than the minimum cost estimated.

As discussed in section 2, the cost efficiency indicators can be used by the government to calculate the individual RRT. This approach would reduce the problem of asymmetric information of the government and improve the productive efficiency of the sector.

\section{Conclusions}

Natural resource extraction can generate an economic rent, i.e. a surplus profit due to a difference between the price at which the resource can be sold and its extraction costs. This so-called resource rent should be the basis for fixing the price for the use of the resource.

In contrast to this optimal rent extraction scheme, the water fee currently paid by Swiss hydropower producers is basically a fixed amount to be paid per kW gross

${ }^{28}$ The variable $D_{R 2}$ does not appear in the table because it is taken as reference, in order to avoid the dummy variable trap. 
capacity. This fee doesn't consider the different cost structure and revenue possibilities of the companies. Since the water fee is not connected to the economic value of the resource it does not enhance allocative efficiency. In addition, the fee system is not neutral to investment decision.

A resource rent would be an interesting alternative to the current water fee system. However, also this system has a drawback since it doesn't include incentives to operate efficiently. In particular, companies might have an incentive problem to produce at a cost minimizing level because the benefits of a cost reduction are captured by the local government through a RRT with a levy rate of $100 \%$. But also with a levy below $100 \%$ companies may not have enough incentives to produce at a cost minimizing point.

To solve the cost inefficiency problem, we propose a new water fee scheme which combines the resource rent tax system with a benchmarking analysis of the production costs of hydropower companies. In this paper, the inefficiency scores used for the computation of the RRT have been estimated using panel data and a TRE stochastic frontier variable costs function. This econometric approach is able to take into account the problem of unobserved heterogeneity.

The paper shows that the econometric estimation of a TRE frontier variable costs function is a feasible and attractive approach. The first results confirm the presence of cost inefficiency which should be considered when computing the RRT. Such a new RRT scheme would improve efficiency and guarantee the long term competitiveness of Swiss hydropower companies. This first analysis shows that there is room for a constructive and innovative change in the method of payment of fees for the use of waterpower.

\section{References}

Aigner, D., Lovell, C.A.K., Schmidt, P., 1977. Formulation and estimation of stochastic frontier production function models. Journal of Econometrics 6, 21-37.

Amundsen, E. S., 1997. Gas Power Production, Surplus Concepts and the Transformation of Hydro Electric Rent into Resource Rent. Resource and Energy Economics, 19(3), 241-259.

Amundsen, E.S., Andersen, C., Sannarnes, J.G., 1992. Rent Taxes on Norwegian Hydropower Generation. The Energy Journal, Vol.13, No.1., 97-116. 
Amundsen, E. S., Tjotta, S., 1993. Hydroelectric Rent and Precipitation Variability: The Case of Norway. Energy Economics, 15(2), 81-91.

Banfi, S., Filippini M., Luchsinger C., 2002. Deregulation of the Swiss Electricity Industry: Short-run Implication for the Hydropower Sector. Electricity Journal, 6, 69-77.

Banfi, S., Filippini, M., Müller, A., 2005. An Estimation of the Swiss Hydropower Rent. Energy Policy 33, 927-937.

Banfi, S., Filippini, M., Luchsinger, C., Müller, A., 2004. Bedeutung der Wasserzinse in der Schweiz und Möglichkeiten einer Flexibilisierung, vdf Hochschulverlag, Zürich.

Battese, G.E., 1992. Frontier production functions and technical efficiency: A survey of empirical applications in agricultural economics. Agricultural Economics, 7, 185208.

Battese, G.E., Coelli, T.J., 1992. Frontier production functions, technical efficiency and panel data: with application to paddy farmers in India. Journal of Productivity Analysis, 3 (1), 153-169.

Bernard, J.-T., 1982. Le Financement de la Confédération: La Rente des Ressource Naturelles. Canadian Public Policy, 8 (3), 297-299.

Caves, D.W., Christensen, L.R., 1988. The importance of economies of scale, capacity utilization and density in explaining inter-industry differences in productivity growth. The Logistics and Transportation Review, 2, 3-32.

Copithorne, L., Macfayden, A., Bell, B., 1985. Revenue Sharing and the Efficient Valuation of Natural Resources. Canadian Public Policy, XI, 465-478.

Cornes, R., 1992. Duality and Modern Economics, Cambridge.

Farsi, M., Filippini, M., Greene, W., 2005. Efficiency measurement in network industries: application to the Swiss railway companies. Journal of Regulatory Economics, 28 (1), 65-86.

Farsi, M., Filippini, M., Kuenzle, M., 2006. Cost Efficiency in Regional Bus Companies: An Application of Alternative Stochastic Frontier Models. Journal of Transport Economics and Policy, 40(1), 95-118. 
Filippini, M., 1996. Economies of Scale and Utilization in the Swiss Electric Power Distribution Industry. Applied Economics, 28, 543-550.

Filippini, M., Luchsinger, C., 2007. Economies of scale in the Swiss hydropower sector. Applied Economic Letters, 14, 1109-1113.

Garnaut, R., Clunies Ross, A., 1975. Uncertainty, risk aversion and the taxing of natural resource projects. The Economic Journal, 85 (338), 272-287.

Gillen, D., Wen, J.-F. 2000. Taxing Hydroelectricity in Ontario. Canadian Public Policy, 26(1), 35-49.

Greene, W., 2005. Reconsidering heterogeneity in panel data estimators of the stochastic frontier model. Journal of Econometrics, 126 (2), 269-303.

Greene, W. H., 2003. Econometric Analysis, $5^{\text {th }}$ edition, Prentice Hall, New Jersey.

Kumbhakar, C.S., Lovell Knox, C.A., 2000. Stochastic Frontier Analysis, Cambridge University Press, Cambridge.

Kumbhakar, S.C., 1991. The measurement and decomposition of cost-efficiency: The translog cost system. Oxford Economic Papers, 43, 667-683.

Pitt, M., Lee, L., 1981. The measurement and sources of technical inefficiency in Indonesian weaving industry. Journal of Development Economics, 9, 43-64.

Polachek, S.W, Yoon, B.J., 1996. Panel Estimates of a Two-Tiered Earnings Frontier. Journal of Applied Econometrics, 11(2), 169-78.

Ricardo, D., 1817. On the Principles of Political Economy, and Taxation, John Murray, London.

Rothman, M., 2000. Measuring and apportioning rents from hydroelectric power developments. World Bank Discussion Paper, No. 419.

Schmidt, P., Sickles, R.C., 1984. Production frontiers and panel data. Journal of Business and Economic Statistics, 2 (4), 367-374.

Van Kooten, G. C., Bulte, E. H., 2000. The economics of nature: managing biological assets, Malden, Mass, Blackwell.

Watkins, G. C., 2001. Altlantic petroleum royalties: fair deal of raw deal? The AIMS (Atlantic Institute for Market Studies) Oil and Gas Papers, Paper No. 2. 


\section{QUADERNI DELLA FACOLTÀ}

1998:

P. Balestra, Efficient (and parsimonious) estimation of structural dynamic error component models

1999:

M. Filippini, Cost and scale efficiency in the nursing home sector : evidence from Switzerland

L. Bernardi, I sistemi tributari di oggi : da dove vengono e dove vanno

L.L. Pasinetti, Economic theory and technical progress

G. Barone-Adesi, K. Giannopoulos, L. Vosper, VaR without correlations for portfolios of derivative securities

G. Barone-Adesi, Y. Kim, Incomplete information and the closed-end fund discount

G. Barone-Adesi, W. Allegretto, E. Dinenis, G. Sorwar, Valuation of derivatives based on CKLS interest rate models

M. Filippini, R. Maggi, J. Mägerle, Skalenerträge und optimale Betriebsgrösse bei den schweizerische Privatbahnen

E. Ronchetti, F. Trojani, Robust inference with GMM estimators

G.P. Torricelli, I cambiamenti strutturali dello sviluppo urbano e regionale in Svizzera e

nel Ticino sulla base dei dati dei censimenti federali delle aziende 1985, 1991 e 1995

2000:

E. Barone, G. Barone-Adesi, R. Masera, Requisiti patrimoniali, adeguatezza del capitale e gestione del rischio

G. Barone-Adesi, Does volatility pay?

G. Barone-Adesi, Y. Kim, Incomplete information and the closed-end fund discount

$\mathrm{R}$. Ineichen, Dadi, astragali e gli inizi del calcolo delle probabilità

W. Allegretto, G. Barone-Adesi, E. Dinenis, Y. Lin, G. Sorwar, A new approach to check the free boundary of single factor interest rate put option

G.D.Marangoni, The Leontief Model and Economic Theory

B. Antonioli, R, Fazioli, M. Filippini, // servizio di igiene urbana italiano tra concorrenza e monopolio

L. Crivelli, M. Filippini, D. Lunati. Dimensione ottima degli ospedali in uno Stato federale

L. Buchli, M. Filippini, Estimating the benefits of low flow alleviation in rivers: the case of the Ticino River

L. Bernardi, Fiscalità pubblica centralizzata e federale: aspetti generali e il caso italiano attuale

M. Alderighi, R. Maggi, Adoption and use of new information technology

F. Rossera, The use of log-linear models in transport economics: the problem of

commuters' choice of mode

2001:

M. Filippini, P. Prioni, The influence of ownership on the cost of bus service provision in

Switzerland. An empirical illustration

B. Antonioli, M. Filippini, Optimal size in the waste collection sector

B. Schmitt, La double charge du service de la dette extérieure

L. Crivelli, M. Filippini, D. Lunati, Regulation, ownership and efficiency in the Swiss

nursing home industry

S. Banfi, L. Buchli, M. Filippini, Il valore ricreativo del fiume Ticino per i pescatori

L. Crivelli, M. Filippini, D. Lunati, Effizienz der Pflegeheime in der Schweiz 
2002:

B. Antonioli, M. Filippini, The use of a variable cost function in the regulation of the Italian water industry

B. Antonioli, S. Banfi, M. Filippini, La deregolamentazione del mercato elettrico svizzero e implicazioni a breve termine per l'industria idroelettrica

M. Filippini, J. Wild, M. Kuenzle, Using stochastic frontier analysis for the access price regulation of electricity networks

G. Cassese, On the structure of finitely additive martingales

2003:

M. Filippini, M. Kuenzle, Analisi dell'efficienza di costo delle compagnie di bus italiane e svizzere

C. Cambini, M. Filippini, Competitive tendering and optimal size in the regional bus transportation industry

L. Crivelli, M. Filippini, Federalismo e sistema sanitario svizzero

L. Crivelli, M. Filippini, I. Mosca, Federalismo e spesa sanitaria regionale : analisi empirica per i Cantoni svizzeri

M. Farsi, M. Filippini, Regulation and measuring cost efficiency with panel data models : application to electricity distribution utilities

M. Farsi, M. Filippini, An empirical analysis of cost efficiency in non-profit and public nursing homes

F. Rossera, La distribuzione dei redditi e la loro imposizione fiscale : analisi dei dati fiscali svizzeri

L. Crivelli, G. Domenighetti, M. Filippini, Federalism versus social citizenship :

investigating the preference for equity in health care

M. Farsi, Changes in hospital quality after conversion in ownership status

G. Cozzi, O. Tarola, Mergers, innovations, and inequality

M. Farsi, M. Filippini, M. Kuenzle, Unobserved heterogeneity in stochastic cost frontier models : a comparative analysis

2004:

G. Cassese, An extension of conditional expectation to finitely additive measures

$\mathrm{S}$. Demichelis, O. Tarola, The plant size problem and monopoly pricing

F. Rossera, Struttura dei salari 2000 : valutazioni in base all'inchiesta dell'Ufficio federale di statistica in Ticino

M. Filippini, M. Zola, Economies of scale and cost efficiency in the postal services : empirical evidence from Switzerland

F. Degeorge, F. Derrien, K.L. Womack, Quid pro quo in IPOs : why book-building is dominating auctions

M. Farsi, M. Filippini, W. Greene, Efficiency measurement in network industries : application to the Swiss railway companies

L. Crivelli, M. Filippini, I. Mosca, Federalism and regional health care expenditures : an empirical analysis for the Swiss cantons

S. Alberton, O. Gonzalez, Monitoring a trans-border labour market in view of liberalization : the case of Ticino

M. Filippini, G. Masiero, K. Moschetti, Regional differences in outpatient antibiotic consumption in Switzerland

A.S. Bergantino, S. Bolis, An adaptive conjoint analysis of freight service alternatives :

evaluating the maritime option

2005:

M. Farsi, M. Filippini, An analysis of efficiency and productivity in Swiss hospitals

M. Filippini, G. Masiero, K. Moschetti, Socioeconomic determinants of regional

differences in outpatient antibiotic consumption : evidence from Switzerland 
2006:

M. Farsi, L. Gitto, A statistical analysis of pain relief surgical operations

M. Farsi, G. Ridder, Estimating the out-of-hospital mortality rate using patient discharge data

S. Banfi, M. Farsi, M. Filippini, An empirical analysis of child care demand in Switzerland

L. Crivelli, M. Filippini, Regional public health care spending in Switzerland : an empirical analysis

M. Filippini, B. Lepori, Cost structure, economies of capacity utilization and scope in Swiss higher education institutions

M. Farsi, M. Filippini, Effects of ownership, subsidization and teaching activities on hospital costs in Switzerland

M. Filippini, G. Masiero, K. Moschetti, Small area variations and welfare loss in the use of antibiotics in the community

A. Tchipev, Intermediate products, specialization and the dynamics of wage inequality in the US

A. Tchipev, Technological change and outsourcing : competing or complementary explanations for the rising demand for skills during the 1980s?

2007:

M. Filippini, G. Masiero, K. Moschetti, Characteristics of demand for antibiotics in primary care : an almost ideal demand system approach

G. Masiero, M. Filippini, M. Ferech, H. Goossens, Determinants of outpatient antibiotic consumption in Europe : bacterial resistance and drug prescribers

R. Levaggi, F. Menoncin, Fiscal federalism, patient mobility and the soft budget constraint : a theoretical approach

M. Farsi, The temporal variation of cost-efficiency in Switzerland's hospitals : an application of mixed models

2008:

Quaderno n. 08-01

M. Farsi, M. Filippini, D. Lunati, Economies of scale and efficiency measurement in

Switzerland's nursing homes

Quaderno n. 08-02

A. Vaona, Inflation persistence, structural breaks and omitted variables : a critical view Quaderno n. 08-03

A. Vaona, The sensitivity of non parametric misspecification tests to disturbance autocorrelation

Quaderno n. 08-04

A. Vaona, STATA tip : a quick trick to perform a Roy-Zellner test for poolability in STATA Quaderno n. 08-05

A. Vaona, R. Patuelli, New empirical evidence on local financial development and growth Quaderno n. 08-06

C. Grimpe, R. Patuelli, Knowledge production in nanomaterials : an application of spatial filtering to regional system of innovation

Quaderno n. 08-07

A. Vaona, G. Ascari, Regional inflation persistence : evidence from Italy Quaderno n. 08-08

M. Filippini, G. Masiero, K. Moschetti, Dispensing practices and antibiotic use Quaderno n. 08-09

T. Crossley, M. Jametti, Pension benefit insurance and pension plan portfolio choice 
Quaderno n. 08-10

R. Patuelli, A. Vaona, C. Grimpe, Poolability and aggregation problems of regional innovation data : an application to nanomaterial patenting

Quaderno n. 08-11

J.H.L. Oud, H. Folmer, R. Patuelli, P. Nijkamp, A spatial-dependence continuous-time model for regional unemployment in Germany

2009:

Quaderno n. 09-01

J.G. Brida, S. Lionetti, W.A. Risso, Long run economic growth and tourism : inferring from Uruguay

Quaderno n. 09-02

R. Patuelli, D.A. Griffith, M. Tiefelsdorf, P. Nijkamp, Spatial filtering and eigenvector stability : space-time models for German unemployment data

Quaderno n. 09-03

R. Patuelli, A. Reggiani, P. Nijkamp, N. Schanne, Neural networks for cross-sectional employment forecasts : a comparison of model specifications for Germany

Quaderno n. 09-04

A. Cullmann, M. Farsi, M. Filippini, Unobserved heterogeneity and International benchmarking in public transport

Quaderno n. 09-05

M. Jametti, T. von Ungern-Sternberg, Hurricane insurance in Florida

Quaderno n. 09-06

S. Banfi, M. Filippini, Resource rent taxation and benchmarking : a new perspective for the Swiss hydropower sector 